\title{
The Impact of Work-Family Conflict on Hedonic Consumption: A Survey on Industrial Workers
}

\section{İnci ERDOĞAN TARAKÇI iD a , Bora GÖKTAŞ iD b}

aBilecik Şeyh Edebali University, Faculty of Health Sciences, Department of Health Management, Bilecik, Turkey. inci.erdgn@hotmail.com bBayburt University, Faculty of Applied Sciences, Department of Management Information Systems, Bayburt, Turkey boragoktas@bayburt.edu.tr

\begin{tabular}{|c|c|}
\hline ARTICLE INFO & ABSTRACT \\
\hline $\begin{array}{l}\text { Keywords: } \\
\text { Work-Family Conflict } \\
\text { Family-Work Conflict } \\
\text { Consumer Behavior } \\
\text { Hedonic Consumption. } \\
\text { Received } 1 \text { August } 2019 \\
\text { Revised } 16 \text { September } 2019 \\
\text { Accepted } 20 \text { September } 2019\end{array}$ & 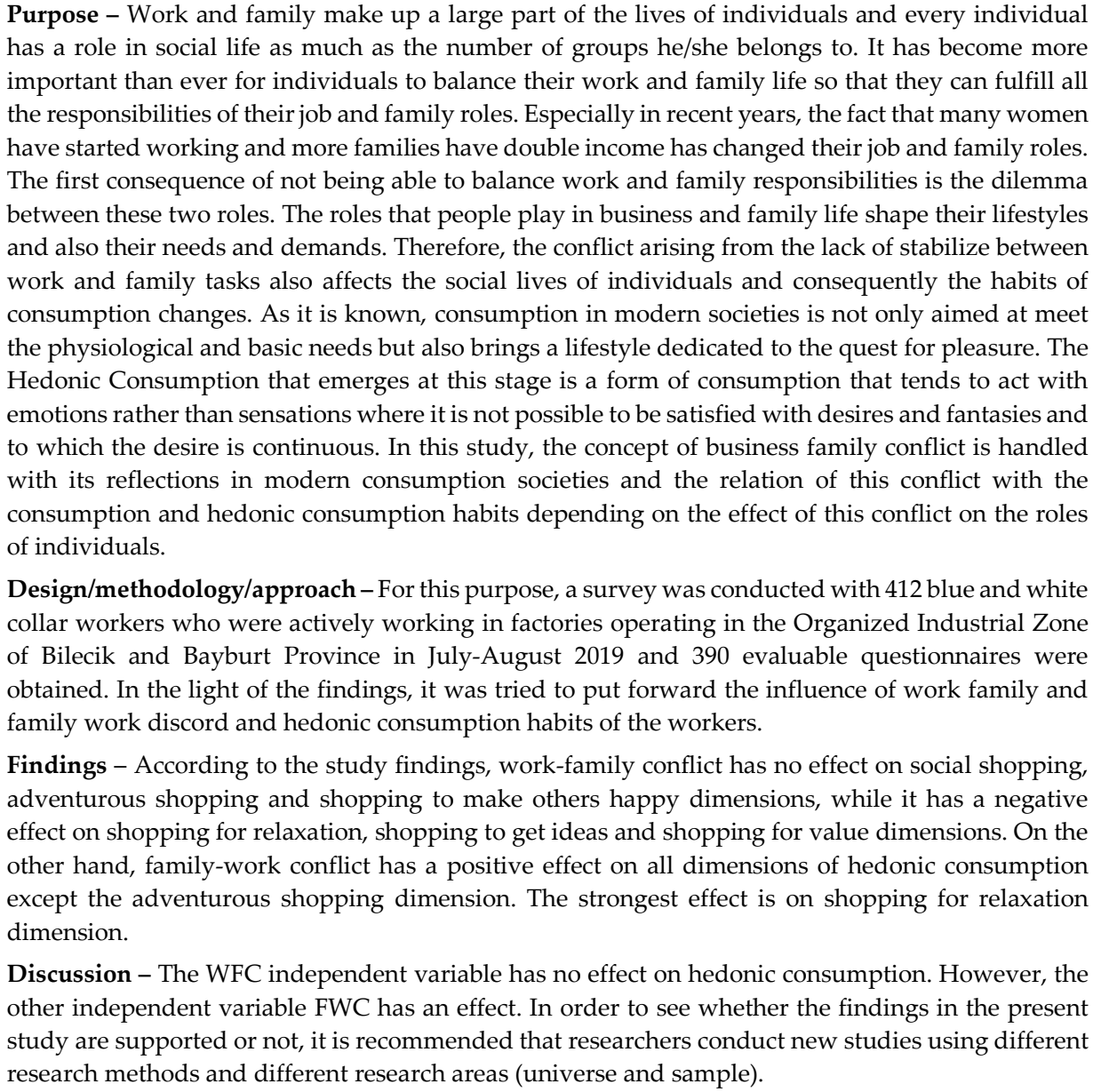 \\
\hline
\end{tabular}

\section{INTRODUCTION}

Every individual has a role in social life as much as the number of groups he/she is a member of. Globalization and rapid change due to technological, political, cultural and economic developments also change the perceptions of individuals about their roles. In particular, many women nowadays enter into working life and more families have double income; it changes the roles of work and family, and also the lifestyles and consumption habits of the individuals. 


\section{İ. Erdoğan Tarakçı - B. Göktaş 11/3 (2019) 2216-2230}

Inevitably existing specialization in today's organizations brings with it coordination. The growth of organizations and the increasing competition in the market have also affected the structure of consumption. This effect is also visible in work and family life (Aktepe and Uygur, 2004: 61).

The study is about the impact of work family conflict on purchasing behavior and especially on hedonic consumption of consumers. As seen in many studies, the Work Family Conflict and Family Work Conflict influence individual's social and work life. Therefore, it directs consumption habits of the individuals. In this study, current studies related to these cases were examined and different approaches and suggestions for the conflicts were analyzed and a research was conducted in Turkey to see the effects of these conflicts on purchasing behavior and hedonic consumption habits of consumers.

\section{WORK-FAMILY CONFLICT AND FAMILY-WORK CONFLICT}

As a social entity, the individual has many organizational and social roles. Role is defined as expectations of the individual from the society (Tolan, 1991: 227). The role is a status behavior that is composed of the sum of the personal and social factors that arise from innate and interpersonal interaction (Erkenekli, 2001: 46). Role behaviors are the attitudes expected from the individuals by the group they are involved in as a requirement of their status in the group.

On the other hand, conflict is defined as the inability or agreement of two or more persons or groups in terms of objectives, desires, aims or motives. In other words, conflict is the state of emotional environments created by conflicts or frictions between individuals and groups in social situations (Schermerhorn et al., 1994: 592). From an individual point of view, conflict is the state of indecision or disagreement experienced by a person who has to choose one of the same or opposite situations (Genç, 2004: 253).

Role conflict is the occurrence of two or more coercive elements in relation to the multiple roles that a person has undertaken simultaneously and the fact that the person is in harmony with one of these roles makes it difficult to be in harmony with the other role (Jackson and Schuler, 1985: 34). Role conflict involving common elements such as indecisiveness, anxiety, strain, depression, tension does not occur only in cases where the individual performs more than one role behavior (Erdoğan, 1994: 90). The inconsistency between the behaviors of the person and the expected behaviors can be defined as role conflict (Koçel, 2001: 413). In other words, role conflict can be explained as the negative difference between what one should do and what he/she does (Erdoğan, 1994: 157).

Work family conflict is a type of conflict between roles that cause from the pressure of simultaneous task demands arising from work and family (Greenhaus and Beutell, 1985). In work-family conflict, due to the excessive role burden, it is possible for an individual to prevent one role from performing the other role and there may be a two-way conflict (Gutek et al., 1991). In the work-family conflict, job demands prevent the person from fulfilling his / her roles and responsibilities in the family-work conflict, while family demands and expectations in the family-work conflict can prevent the person from fulfilling his / her roles and responsibilities (Frone et al., 1992). However, it is emphasized that work-family conflict occurs about three times more than family-work conflict (Frone et al., 1992) and work tensions are positively related to workfamily conflict (Greenhaus and Beutell, 1985; Voydanoff, 1988).

In recent years, it is seen that Work-Family Conflict and Family-Work Conflict is an important research domain because of their influences on individual's work and social life. Also life and job satisfaction, quality of marriages, child care, and other cases are effected by this conflict. A detailed literature review has been made and current studies about the conflict were analyzed. And it is seen that still there is a need to answer some other questions to reduce the conflict or lower the effects.

There are different studies that suggest different ideas from different approaches to the conflict. Especially in meta-analyses studies, the gaps have been pointed out for the future studies to be examined. 
Table 1: Work-Family Conflict Literature Review

\begin{tabular}{|c|c|c|}
\hline Author & Year & Suggestions \\
\hline $\begin{array}{l}\text { Jesse S. Michel, Jacqueline K. } \\
\text { Mitchelson, Lindsey M. } \\
\text { Kotrba, James M. LeBreton, } \\
\text { Boris B. Baltes }\end{array}$ & 2008 & $\begin{array}{l}\text { Direct impacts lead to work-family conflict models while indirect } \\
\text { impacts result in a small gradual explication of contentment } \\
\text { issues. }\end{array}$ \\
\hline Kristin Byron & 2003 & $\begin{array}{l}\text { The analysis confirms the idea that WIF and FIW have unique } \\
\text { precursors, and so, may require various actions or remedies to } \\
\text { hinder or minimize their emergence and also suggest that } \\
\text { demographic characteristics like gender and marital status alone } \\
\text { are poor predictors of work-family conflict. }\end{array}$ \\
\hline $\begin{array}{c}\text { Osman M. Karatepe, Orhan } \\
\text { Uludağ }\end{array}$ & 2008 & $\begin{array}{l}\text { Family-work conflict affects marriage satisfaction negatively and } \\
\text { marriage satisfaction negatively affects the employee's turnover } \\
\text { intentions. }\end{array}$ \\
\hline $\begin{array}{l}\text { Julie Holliday Wayne, } \\
\text { Nicholas Musisca, and William } \\
\text { Fleeson }\end{array}$ & 2002 & $\begin{array}{l}\text { Conflict is negatively associated with work-family outcomes (eg } \\
\text { low work and family effort and satisfaction), while facilitation is } \\
\text { positively associated with the same outcomes. }\end{array}$ \\
\hline $\begin{array}{l}\text { Dawn S. Carlson, K. Michele } \\
\text { Kacmar and Larry J. Williams }\end{array}$ & 2000 & $\begin{array}{l}\text { The six elements of the measured conflict contain the } \\
\text { composition of three versions of work-family conflicts (time, } \\
\text { strain and behavior) and two work-family conflicts (work } \\
\text { interference with family and family interference with work). The } \\
\text { study gives future researchers the elasticity to individually } \\
\text { measure any of the six elements of work-family conflict. }\end{array}$ \\
\hline $\begin{array}{l}\text { Jessica R. Mesmer-Magnus, } \\
\text { Chockalingam Viswesvaran }\end{array}$ & 2003 & $\begin{array}{l}\text { Relationships between two modes of work / family conflict and } \\
\text { other factors like commitment to the organization, work and life } \\
\text { contentment level and health were researched. Results are } \\
\text { discussed for the distinctive effectiveness of two shapes of } \\
\text { conflict. }\end{array}$ \\
\hline $\begin{array}{l}\text { Denise M. Rotondo, Dawn S. } \\
\text { Carlson, Joel F. Kincaid }\end{array}$ & 2003 & $\begin{array}{l}\text { One way to diminish work-family conflict is to enable } \\
\text { individuals to effectively cope with stressful demands. The } \\
\text { results show that individuals can have more check and occasion } \\
\text { for favorable alter in the family field compared to the working } \\
\text { surroundings. }\end{array}$ \\
\hline $\begin{array}{l}\text { Tammy D. Allen, Ryan C. } \\
\text { Johnson, Kristin N. Saboe, } \\
\text { Eunae Cho, Soner Dumani, } \\
\text { Sarah Evans }\end{array}$ & 2011 & $\begin{array}{l}\text { No moderate effect was found for gender, parental status or } \\
\text { marital status. The findings confirm the idea that dispositions are } \\
\text { significant determinants of work-family conflict. }\end{array}$ \\
\hline $\begin{array}{l}\text { Xinyuan (Roy) Zhao, Hailin } \\
\text { Qu, Richard Ghiselli }\end{array}$ & 2011 & $\begin{array}{l}\text { This paper showed that both the work interfering with family } \\
\text { (WIF) and the family conflicting with work (FIW) had a } \\
\text { significant negative relationship with the emotional response of } \\
\text { an individual to his / her work. In addition, affective response } \\
\text { rather than cognitive assessment showed a significant positive } \\
\text { correlation with life satisfaction. }\end{array}$ \\
\hline Tammy D. Allen & 2001 & $\begin{array}{l}\text { The study underlines the important role that perceptions of the } \\
\text { general working environment play in determining employees' } \\
\text { response to family-friendly social assistance policies. }\end{array}$ \\
\hline $\begin{array}{l}\text { Laurent M. Lapierre, Paul E. } \\
\text { Spector, Tammy D. Allen, } \\
\text { Steven Poelmans, Cary L. } \\
\text { Cooper, Michael P. O'Driscoll, } \\
\text { Juan I. Sanchez, Paula Brough, } \\
\text { Ulla Kinnunen }\end{array}$ & 2008 & $\begin{array}{l}\text { The results show that personnels working in an environment } \\
\text { seen as more encouraging experience in a family lower their } \\
\text { WFC levels. Decreasing WFC means more job and family } \\
\text { satisfaction, then more overall life satisfaction. }\end{array}$ \\
\hline
\end{tabular}




\begin{tabular}{|c|c|c|}
\hline $\begin{array}{l}\text { Rachel Gali Cinamon and } \\
\text { Yisrael Rich }\end{array}$ & 2002 & $\begin{array}{l}\text { Women are more suited to the family profile, while men are } \\
\text { more prone to the job profile. There was no gender difference for } \\
\text { the dual profile. In the study, the value that women attach to } \\
\text { parenting and work issues is more than men. Therefore, there is a } \\
\text { significant difference between men and women in terms of } \\
\text { gender variable in the work-family conflict. }\end{array}$ \\
\hline $\begin{array}{l}\text { Marco S. DiRenzo, Jeffrey H. } \\
\text { Greenhaus, Christy H. Weer }\end{array}$ & 2011 & $\begin{array}{l}\text { The results show that senior employees experience more conflicts } \\
\text { in both directions than subordinate employees, and that work } \\
\text { and home based resources are associated differently with those } \\
\text { of workers with lower and higher level jobs. }\end{array}$ \\
\hline $\begin{array}{l}\text { Jesse S. Michel, Michael B. } \\
\text { Hargis }\end{array}$ & 2008 & $\begin{array}{l}\text { In the study, it is argued that the indirect effect of work-family } \\
\text { conflict models explained } 2.20 \% \text { and } 6.20 \% \text { of the variance in } \\
\text { work and family satisfaction results, and direct impact } \\
\text { segmentation models explained } 54.10 \% \text { and } 48.50 \% \text { of the results } \\
\text { of work and family satisfaction. }\end{array}$ \\
\hline $\begin{array}{l}\text { Albena Z. Stoeva, Randy K. } \\
\text { Chiu and Jeffrey H. Greenhaus }\end{array}$ & 2002 & $\begin{array}{l}\text { The study found that the positive correlation between family } \\
\text { stress and F> W conflict was stronger in individuals with high- } \\
\text { NA than those with low-NA. }\end{array}$ \\
\hline $\begin{array}{l}\text { Mahmut Özdevecioğlu and } \\
\text { Nihal Çakmak Doruk }\end{array}$ & 2009 & $\begin{array}{l}\text { The study shows that work-family conflict negatively affects } \\
\text { work satisfaction, but family work conflict significantly affects } \\
\text { work satisfaction. In addition, there is a positive correlation } \\
\text { between work-family conflict and family-work conflict. }\end{array}$ \\
\hline Dawn S. Carlson & 1999 & $\begin{array}{l}\text { The study claims that each of the shapes of conflict has its own } \\
\text { set of precursors, and that dispositional variables are important } \\
\text { additional differences beyond the condition in three ways of } \\
\text { work-family conflict (time, strain and behavior-based conflicts). }\end{array}$ \\
\hline $\begin{array}{l}\text { Nahren Ishaya and Roya } \\
\text { Ayman }\end{array}$ & 2008 & $\begin{array}{l}\text { The study shows that there are significant differences in } \\
\text { predicting various forms and aspects of work-family conflict. }\end{array}$ \\
\hline $\begin{array}{l}\text { Michael R. Frone, Marcia } \\
\text { Russell and M. Lynne Cooper }\end{array}$ & 1997 & $\begin{array}{l}\text { The study shows that family - work conflict is correlated with } \\
\text { high grades of depression and poor physical health and the } \\
\text { incidence of hypertension. On the other hand, work - family } \\
\text { conflict is associated with high levels of alcohol consumption. }\end{array}$ \\
\hline $\begin{array}{l}\text { Amy Antani Logue and Roya } \\
\text { Ayman }\end{array}$ & 2009 & $\begin{array}{l}\text { The study shows that the impact of support received from work } \\
\text { and family domains is different on WIF \& FIW as well as on } \\
\text { turnover intentions. }\end{array}$ \\
\hline $\begin{array}{l}\text { Jeffrey H. Greenhaus and } \\
\text { Nicholas J. Beutell }\end{array}$ & 1985 & $\begin{array}{l}\text { The study shows that the work-family conflict occurs when: (a) } \\
\text { the time allocated to the necessities of one role makes it } \\
\text { complicate to meet the conditions of another; (b) the obligation to } \\
\text { take part in one role makes it complicate to implement the } \\
\text { requirements of another; and (c) the certain behaviors needed by } \\
\text { one role make it complicate to implement the requirements of } \\
\text { another. }\end{array}$ \\
\hline $\begin{array}{l}\text { Carly S. Bruck, Tammy D. } \\
\text { Allen, and Paul E. Spector }\end{array}$ & 2002 & $\begin{array}{l}\text { The results emphasize the significance of pay attention to both } \\
\text { the form and direction of WFC and propose a variety of practical } \\
\text { applications for organizations. }\end{array}$ \\
\hline $\begin{array}{l}\text { Dawn S. Carlson and Pamela } \\
\text { L. Perrewe }\end{array}$ & 1999 & $\begin{array}{l}\text { In this study, a fuller model of work-family conflict was } \\
\text { improved and analyzed. It discusses how social backing } \\
\text { decreases the possibility of conditions being felt as hard-pressed, } \\
\text { and the implications that indirectly affect work-family conflict } \\
\text { through perceived stressors. }\end{array}$ \\
\hline $\begin{array}{l}\text { J. Mesmer-Magnus and C. } \\
\text { Viswesvaran }\end{array}$ & 2009 & $\begin{array}{l}\text { This study suggests that coworkers have a unique opportunity to } \\
\text { provide family-facilitative support as they understand the nature } \\
\text { of the stressors their employees face. They are also more }\end{array}$ \\
\hline
\end{tabular}




\begin{tabular}{|c|c|c|}
\hline & & $\begin{array}{l}\text { prepared to offer instrumental and emotional assistance to a } \\
\text { coworker struggling to balance conflicting work and family } \\
\text { demands in team-based organizational structures. }\end{array}$ \\
\hline $\begin{array}{l}\text { Troy R. Nielson, Dawn S. } \\
\text { Carlson and } \\
\text { Melenie J. Lankau }\end{array}$ & 2001 & $\begin{array}{l}\text { The study shows that individuals with mentors reported } \\
\text { significantly less work-family conflict, particularly family-work } \\
\text { conflict, than these participants who did not have mentors and a } \\
\text { mentor's support of a proteges efforts to balance work and } \\
\text { family demands has significant impacts on reducing proteges } \\
\text { work-family conflict and that the role modeling function of } \\
\text { mentoring significantly decreases family-work conflict } \\
\text { experienced by proteges. }\end{array}$ \\
\hline $\begin{array}{l}\text { Zeynep Aycan and Mehmet } \\
\text { Eskin }\end{array}$ & 2005 & $\begin{array}{l}\text { The study reveals that WFC has a negative association with } \\
\text { psychological well-being, marital satisfaction, and parental role } \\
\text { effort for both men and women. The effects of findings in relation } \\
\text { to changing gender roles in the cultural context characterized by } \\
\text { high collectivism and low gender egalitarianism are examined. }\end{array}$ \\
\hline $\begin{array}{c}\text { Dilek Yıldırım and Zeynep } \\
\text { Aycan }\end{array}$ & 2008 & $\begin{array}{l}\text { The study reveals that overwork and irregular work programs } \\
\text { are important elements of work-family conflict, and work-family } \\
\text { conflict is correlated with low work and life satisfaction. } \\
\text { Psychological well-being and organizational attitude can be } \\
\text { improved by reposition working requirements to diminish much } \\
\text { workload and unsteady work condition. In addition, leadership } \\
\text { development programs should be carried out to rise the } \\
\text { instrumental and emotional backing of managers. }\end{array}$ \\
\hline Zeynep Aycan & 2005 & $\begin{array}{l}\text { The study shows that the greatness of the effect of WFC on the } \\
\text { results depends on the way WFC is perceived to harm the most } \\
\text { important area in society. In addition, WIF is expected to be } \\
\text { strongly associated with negative welfare outcomes in cultures } \\
\text { where family is the most important area in life, while FIW is } \\
\text { expected to strongly correlate with negative welfare outcomes in } \\
\text { cultures where the work is the most important area in life. }\end{array}$ \\
\hline $\begin{array}{l}\text { Jeffrey H. Greenhaus, Jonathan } \\
\text { C. Ziegert and Tammy D. } \\
\text { Allen }\end{array}$ & 2012 & $\begin{array}{l}\text { The study shows that the relationship between family supportive } \\
\text { supervision and balance is stronger for employees in the family } \\
\text { supporting organizational environment than for non-supportive } \\
\text { environments and is stronger for employees with supporting } \\
\text { spouses than for non-supporting spouses. }\end{array}$ \\
\hline $\begin{array}{l}\text { Kristen M. Shockley and } \\
\text { Tammy D. Allen }\end{array}$ & 2007 & $\begin{array}{l}\text { The study reveals that FWA relate more highly to work } \\
\text { interference with family (WIF) than to family interference with } \\
\text { work (FIW) and that temporal flexibility (flextime) has a stronger } \\
\text { relationship with WIF than spatial flexibility (flexplace). }\end{array}$ \\
\hline Patricia Voydanoff & 1988 & $\begin{array}{l}\text { The findings show that the duration of work, the amount of work } \\
\text { demands and the presence of children at home are related to the } \\
\text { work / family conflict between men and women. Perceived } \\
\text { control over job status emphasizes some relationships between } \\
\text { work role traits and work / family conflict. }\end{array}$ \\
\hline $\begin{array}{l}\text { Rachel Gali Cinamona and } \\
\text { Yisrael Rich }\end{array}$ & 2005 & $\begin{array}{l}\text { The study shows that the relationships between teacher stress } \\
\text { and support variables and work-family conflict differ from the } \\
\text { patterns in other professions. School level and teacher experience } \\
\text { contributed to explaining the conflict. }\end{array}$ \\
\hline
\end{tabular}

There are many studies about the WFC. As seen above, in some of the studies, the relationship between WFC and FWC is pointed out and suggested that there is no enough study on the relationship between these two concepts. In some other studies, it is suggested that there is a positive side of the WFC that is facilitation. And 


\section{İ. Erdoğan Tarakçı - B. Göktaş 11/3 (2019) 2216-2230}

also there are many ways to reduce the conflict for example segmentation. In some other studies, the forms of conflicts that are: time, strain and behavior, are analyzed. Also it is seen that conflict is greater in WIF direction than FIW direction. And many studies reveal that work family conflict changes the social roles of the individuals.

But still there are gaps in some cases. There is no enough study on the impacts of work family conflict on consumer behavior. Given that business-family conflict changes roles in social life, changes in individuals' lifestyles will lead to changes in needs and wants. Thus, consumption habits will change. This study has the opportunity to be an original study and present a new finding to the literature. It is also a multidisciplinary study since the effects of two different disciplines are tested.

\section{HEDONIC CONSUMPTION}

Purchasing behavior of consumers can sometimes be a simple process or sometimes quite complex. While sometimes the aim is to satisfy a need, sometimes beyond the concrete benefit to be obtained, the shopping process can have a meaning for consumers. In this sense, shopping includes many experiential and emotional reasons as well as rational reasons.

Traditional consumption is to find, buy, use or dispose of a good or service in order to meet basic needs (Odabaş1, 2006: 16). In other words, they are activities aimed at eliminating the physiological basic needs such as eating, drinking and safety or the psychological needs of people such as self-realization and dignity (Torlak, 2017). In modern societies, consumption is not only aimed at satisfying the physiological and basic needs, but also expressing a lifestyle and in this sense, departs from the functional / useful practice of its products.

Today, consumption has become a part of social communication as a sign and code of status, pleasure, identity and social relationship. In other words, consumption is a language that determines how people will be recognized among other people and represents and tells the individual and gives information about the individual.

Consumption behavior is divided into two groups as utilitarian and hedonic. In utilitarian consumption theory, consumers shop for necessity or basic needs. First, a need arises. Subsequently, the consumer buys the most appropriate goods or services among alternatives that are appropriate to the budget of the consumer. In theory, it is accepted that the consumer makes the most benefit from his endless needs with a certain and limited budget within full information by preferring the most to the less (Doğrul, 2012). As stated in Maslow's pyramid of needs, new needs such as aesthetic requirements, respect, trust, appreciation, prestige, success, personal satisfaction and self-fulfillment are emerging for the individual who meets his needs. Thus, utilitarian consumption decreases and is replaced by hedonic consumption.

Hedonism literally; "is the doctrine of indulgence in the degree of enjoy and physical pleasure" or "the development of economic activity to the highest degree of pleasure" (Turkish Language Association). Pleasure, unlike happiness, is very short-lived and temporary. For this reason, consumers are constantly in search of new pleasure and desire to make continuous consumption (Erdoğan Tarakçı and Baş, 2019: 151).

The concept of Hedonic Consumption was first proposed by Hirschman and Holbrook (1982) and was defined as the dimensions of consumer behaviors associated with the excitement resulting from simultaneous appeal to multiple emotions, fantasy and product experiences. According to Hirschman and Holbrook (1982), the characteristics that differentiate hedonic consumption from traditional consumption are intellectual structure, product classes, product use and individual differences.

There are 6 main reasons for hedonic consumption. These; (1) shopping for social purposes, (2) shopping for adventure, (3) shopping for relaxation, (4) shopping to make others happy, (5) shopping for ideas, and (6) shopping for value (Arnould and Reynolds, 2003: 80). Accordingly, consumers shop for the purpose of socializing, having a pleasant time with family and friends, experiencing a sense of adventure, relaxing, making others happy, acquiring ideas about new products and fashion, and having products that are not available to anyone or capturing opportunities.

In the application part of the study, it has been investigated whether the work-family and family-work conflicts experienced by individuals cause a change in their consumption habits and whether they are directed to hedonic consumption as one of the ways to get rid of the negative environment created by conflicts. 


\section{RESEARCH METHODOLOGY}

\subsection{Purpose of Research and Data Collection Tool}

The aim of the study is to determine whether levels of work-family conflict and levels of family-work conflict drive consumers to hedonic consumption behaviors. There are two independent variables, the levels of workfamily conflict and the levels of family-work conflict, and the effect of these two independent variables on hedonic buying behavior is tested. In the research, a questionnaire was prepared as a data collection tool and convenience sampling method was applied. The questionnaire was applied face to face to 412 blue and white collar workers who were actively working in factories operating in Bilecik and Bayburt Organized Industrial Zone between July-August 2019. 22 missing or incorrectly filled questionnaires were eliminated and 390 robust questionnaires were analyzed.

Three scales were used to test the research topic. The first of these is a 5-item work-family conflict scale that tries to reveal the negative reflections of the activities required by the job on family life and responsibilities. The second is a 5-item family-work conflict scale that tries to reveal the reflections of responsibilities and needs of the family on business life. Work-family and family-work conflict scales were taken from Hasyurt's (2017) study "The Relationship Between Work-Family Conflict and Intention to Leave Work: A Case Study of an Enterprise Which Employ Turkish and Chinese Managers in the Energy Sector in Istanbul". The third research scale used in the study was the hedonic consumption scale of Karataş (2011). This scale consists of 22 items. Thus, the scale items of the research consisted of 32 propositions in total. In addition, 14 descriptive questions were directed to the participants and thus the questionnaire consisted of 46 questions in total.

In this study, it is tried to see whether the work-family conflicts and family-work conflicts of the participants lead to hedonic consumption. In other words, the effect of "work-family conflict" scale on "hedonic consumption" scale and "family-work conflict" scale on "hedonic consumption" scale were tried to be determined. If both scales have an effect on hedonic consumption, it is aimed to understand which one has the most effect. In this respect, the study has the opportunity to be an original study and present a new finding to the literature. It is also a multidisciplinary study since the effects of two different disciplines (management and organization and marketing) are tested.

\subsection{Limitations of the Research}

The biggest limitation of the study is that convenience sampling method was chosen. At the same time, since the questionnaires were applied to workers in a busy time and in a noisy factory environment, it was assumed that the questions were understood correctly and that the employees gave objective answers especially to the work-family conflict scales. The choice of random sampling methods in future studies will be more effective in terms of generalizability of the study. Another limitation of the study is that the research is limited to Bilecik and Bayburt provinces due to cost constraints.

\subsection{Research Hypotheses}

The hypotheses of the study were designed in accordance with the dependent and independent variables mentioned in the research purpose. In the study, there are 2 independent variables (work-family conflict dimension and family-work conflict dimension) and 6 dependent variables of hedonic consumption scale. Accordingly, the hypotheses of the research are as follows;

H1: Work-family conflict has a positive impact on the social shopping dimension,

H2: Work-family conflict has a positive impact on the adventurous shopping dimension,

H3: Work-family conflict has a positive impact on the shopping for relaxation dimension,

H4: Work-family conflict has a positive impact on the shopping to make others happy dimension,

H5: Work-family conflict has a positive impact on the shopping to get ideas dimension,

H6: Work-family conflict has a positive impact on the shopping for value dimension,

H7: Family-work conflict has a positive impact on social shopping dimension,

H8: Family-work conflict has a positive impact on the adventurous shopping dimension, 


\section{İ. Erdoğan Tarakçı - B. Göktaş 11/3 (2019) 2216-2230}

H9: Family-work conflict has a positive impact on shopping for relaxation dimension,

H10: Family-work conflict has a positive impact on shopping to make others happy dimension,

H11: Family-work conflict has a positive impact on shopping get ideas dimension,

H12: Family-work conflict has a positive impact on the shopping for value dimension.

\subsection{Research Reliability and Factor Analysis}

Cronbach's Alpha Coefficient is used to test the reliability of the study. When this coefficient is between 0.81$1.00(0.81 \leq \alpha \leq 1.00)$, it means that the scale is highly reliable (Kıllı̧, 2016: 48).

The Cronbach's Alpha Coefficient of the "Work-Family Life Conflict" scale was 0.899; The "family-work conflict" scale was 0.840 and the "hedonic consumption" scale was 0.815 . According to these results, all three scales used in the study have a high degree of reliability. Table 2 shows these results.

Table 2: Reliability of the Scales Used in the Study

\begin{tabular}{|c|c|c|}
\hline Scale & Cronbach's Alpha & N of Items \\
\hline Work-family Conflict &, 899 & 5 \\
\hline Family-work Conflict &, 840 & 5 \\
\hline Hedonic Consumption &, 815 & 22 \\
\hline
\end{tabular}

Bartlet's sphericity test and KMO (Kaiser-Meyer-Olkin) test results were analyzed to see whether the scales used in the study were suitable for factor analysis. For Bartlet's sphericity test, $\mathrm{p}<0.05$ is required. For the KMO value, the value greater than 0.50 is considered sufficient for the social sciences. Besides, it is assumed that a value between 0.81-0.90 is a good value for the KMO value (Yaşar, 2014: 66).

While the KMO value of the work-family life conflict scale is 0.868 , Bartlet's sphericity test had an approximate square of 1213.423 and a $\mathrm{p}$ value of 0.000 . This scale is collected under a single dimension and can explain $71.609 \%$ of the total variance.

$\mathrm{KMO}$ value of the family-work conflict scale is 0.812 , Bartlet's sphericity test is approximately 761.297 , and $\mathrm{p}$ value is 0.000 , and it is collected under one dimension. This scale explains $61,446 \%$ of the total variance.

Hedonic consumption scale KMO value is 0.871 , Bartlet's sphericity test is approximately square of 4193.470 and $\mathrm{p}$ value is 0.000 . The scale is collected under six dimensions and explained $66.655 \%$ of the total variance. In this scale, the contribution of the first dimension to the total variance is $18.418 \%$; the contribution of the second dimension is $13.614 \%$; the contribution of the third dimension is $12.894 \%$; the contribution of the fourth dimension is $8.355 \%$; the contribution of the fifth dimension is $7.532 \%$ and the contribution of the sixth dimension is $5.843 \%$.

\section{RESULTS AND FINDINGS}

In this section, information about demographic characteristics and other descriptive findings is given and the regression test is conducted for the basic hypotheses of the research.

\subsection{Demographic Findings}

$60.8 \%$ of the participants are men; $39.2 \%$ are women and $56.9 \%$ are married and $43.1 \%$ are single; $29.2 \%$ of them are between $25-34$ years old, $29.2 \%$ of them are between $35-44$ years old, $23.8 \%$ of them are between 18 24 years old, $10.8 \%$ of them are between $45-54$ years old and $6,9 \%$ of them are 55 years old and over.

$47.7 \%$ of the sample are high school graduates, $23.8 \%$ of them are undergraduate, $9.2 \%$ of them are secondary school and equivalent, $7.7 \%$ of them are associate, $6.9 \%$ of them are primary school and $4.6 \%$ of them are masters or PhD graduates. 
İ. Erdoğan Tarakçı - B. Göktaş 11/3 (2019) 2216-2230

42.3\% of them have individual income between 3001-4000 TL, $22.3 \%$ between 2001-3000 TL, $14.6 \%$ between 4001-5000 TL, $10.8 \%$ between 1001-2000 TL, $5.4 \%$ over 5000 TL and $4.6 \%$ have individual income between 0$1000 \mathrm{TL}$.

Table 3: Demographic Characteristics of the Sample

\begin{tabular}{|c|c|c|c|}
\hline VARIABLE & GROUPS & FREQUENCY & $\%$ \\
\hline \multirow[t]{2}{*}{ GENDER } & Woman & 153 & 39.2 \\
\hline & Man & 237 & 60.8 \\
\hline \multirow[t]{2}{*}{ MARITAL STATUS } & Married & 225 & 56.9 \\
\hline & Single & 165 & 43.1 \\
\hline \multirow{5}{*}{ AGE } & $18-24$ & 93 & 23.8 \\
\hline & $25-34$ & 114 & 29.2 \\
\hline & $35-44$ & 114 & 29.2 \\
\hline & $45-54$ & 42 & 10.8 \\
\hline & +55 & 27 & 6.9 \\
\hline \multirow{6}{*}{ EDUCATION } & Primary school & 27 & 6.9 \\
\hline & Secondary School and Equivalent & 36 & 9.2 \\
\hline & High school & 186 & 47.7 \\
\hline & Associate & 30 & 7.7 \\
\hline & Undergraduate & 93 & 23.8 \\
\hline & Graduate (Masters/PhD) & 18 & 4.6 \\
\hline \multirow{6}{*}{$\begin{array}{l}\text { INDIVIDUAL INCOME } \\
\text { STATUS }\end{array}$} & $0-1000$ & 18 & 4.6 \\
\hline & $1001-2000$ & 42 & 10.8 \\
\hline & $2001-3000$ & 87 & 22.3 \\
\hline & $3001-4000$ & 165 & 42.3 \\
\hline & $4001-5000$ & 57 & 14.6 \\
\hline & +5001 & 21 & 5.4 \\
\hline
\end{tabular}

\subsection{Other Descriptive Findings}

In this section, some of the main questions have been asked, depending on the work on family-work conflict and family-work conflict. Since $43.1 \%$ of the participants were single, they answered the question "what is your spouse's working status?" as "I have no spouse". Among the $57.7 \%$ of the married participants, the spouses of $31.5 \%$ were full-time and $22.3 \%$ were not employed.

$44.6 \%$ of the respondents answered more than 40 hours to the question of how many hours a week they work in the workplace. $30 \%$ of them are working for 40 hours and $25.4 \%$ of them are working for less than 40 hours per week.

$45.4 \%$ of the sample has a working life of $1-5$ years. $21.5 \%$ of them $6-10$ years, $12.3 \%$ of them $16-20$ years, 12.3 $\%$ of them more than 20 years and $8.5 \%$ of them have $11-15$ years of working life.

$46.2 \%$ have no children, $20 \%$ have 1 child, $20 \%$ have 2 children, $10 \%$ have 3 children, $2.3 \%$ have 4 and $1.5 \%$ have more than 5 children. $50 \%$ of those who have children are of preschool age. All participants are Turkish citizens. 
$9.2 \%$ of the participants stated that they always, $13.2 \%$ often, $44.6 \%$ sometimes, $23.8 \%$ rarely make shopping by making sudden decisions without planning and $8.5 \%$ of them stated that they have never done such a thing.

In response to the question, "Would you stop buying a product you need to buy a product you like and enjoy buying?, 3.8\% of the participants said "always", $10.8 \%$ often, 30\% sometimes, $25.4 \%$ rarely and $30 \%$ said "never".

As the last descriptive question, 36.2\% of the participants stated that they go shopping 2-3 times a month, $25.4 \% 1$ or less per month, $10.8 \% 1$ time per week, $21.5 \% 2-3$ times a week and $6.2 \%$ every day. Descriptive findings are presented in Table 4.

Table 4: Other Descriptive Findings

\begin{tabular}{|c|c|c|c|}
\hline VARIABLE & Groups & FREQUENCY & $\%$ \\
\hline \multirow[t]{5}{*}{ Your Spouse's Work Status } & I have no wife & 168 & 43.1 \\
\hline & Not working & 87 & 22.3 \\
\hline & Working part time & 3 & 0.8 \\
\hline & Working full time & 123 & 31.5 \\
\hline & Retired & 9 & 2.3 \\
\hline \multirow[t]{3}{*}{ Weekly Working Hours } & Less than 40 hours & 99 & 25.4 \\
\hline & 40 & 117 & 30.0 \\
\hline & More than 40 hours & 174 & 44.6 \\
\hline \multirow[t]{5}{*}{ Work Period } & $1-5$ years & 177 & 45.4 \\
\hline & 6-10 years & 84 & 21.5 \\
\hline & $11-15$ years & 33 & 8.5 \\
\hline & 16-20 years & 48 & 12.3 \\
\hline & +20 years & 48 & 12.3 \\
\hline \multirow[t]{6}{*}{ Number of children } & 0 & 180 & 46.2 \\
\hline & One & 78 & 20.0 \\
\hline & 2 & 78 & 20.0 \\
\hline & 3 & 39 & 10.0 \\
\hline & 4 & 9 & 2.3 \\
\hline & +5 & 6 & 1.5 \\
\hline \multirow{2}{*}{$\begin{array}{c}\text { Do you have children at } \\
\text { preschool age? }\end{array}$} & Yes & 105 & 26.9 \\
\hline & No & 285 & 73.1 \\
\hline \multirow{5}{*}{$\begin{array}{c}\text { Do you shop by making } \\
\text { sudden decisions without } \\
\text { planning? }\end{array}$} & Always & 36 & 9.2 \\
\hline & Often & 54 & 13.8 \\
\hline & Sometimes & 174 & 44.6 \\
\hline & Rarely & 93 & 23.8 \\
\hline & Never & 33 & 8.5 \\
\hline \multirow{5}{*}{$\begin{array}{l}\text { Would you stop buying a } \\
\text { product you need to buy a } \\
\text { product you like and enjoy? }\end{array}$} & Always & 15 & 3.8 \\
\hline & Often & 42 & 10.8 \\
\hline & Sometimes & 117 & 300 \\
\hline & Rarely & 99 & 25.4 \\
\hline & Never & 117 & 30.0 \\
\hline \multirow{5}{*}{$\begin{array}{c}\text { On average how often do you } \\
\text { shop? }\end{array}$} & 1 or less per month & 99 & 25.4 \\
\hline & 2-3 times a month & 141 & 36.2 \\
\hline & 1 time per week & 42 & 10.8 \\
\hline & 2-3 times a week & 84 & 21.5 \\
\hline & Everyday & 24 & 6.2 \\
\hline
\end{tabular}




\subsection{Regression Analysis}

Multiple regression analysis was performed to test the hypotheses listed in the hypotheses of the study. In multiple regression analysis, the effect of multiple independent variables on dependent variables is tested. Table 5 gives the analysis results. The research hypotheses were established that the independent variable had a positive effect on the dependent variable (as the independent variable increased, the dependent variable also increased). Therefore, even if $\mathrm{p}<0.05$ in models 3,5 and 6 , the hypothesis of these models can be rejected since the effect of the independent variable on the dependent variables is negative.

In addition, since the model is $\mathrm{p}>0.05$ for $1,2,4$ and 8 , the hypotheses generated for these models can be rejected. In this case, the hypotheses $\mathrm{H} 1, \mathrm{H} 2, \mathrm{H} 3, \mathrm{H} 4, \mathrm{H} 5, \mathrm{H} 6$ and $\mathrm{H} 8$ of the study cannot be accepted. On the other hand, the other 5 models (models 7, 9, 10, 11 and 12) had a positive effect of the independent variable on the dependent variable. Thus, the hypotheses H7, H9, H10, H11 and H12 of the study can be supported.

Particularly in model 9, $\beta=0.805$ has a very high effect. A 1-unit change in the family-business conflict size leads to a change of 0.805 units on the shopping dimension to relax. The model with the least effect on accepted hypotheses is 12 . In this model, $\beta=0.390$.

Table 5: Multiple Regression Analysis Results

\begin{tabular}{|c|c|c|c|c|c|c|}
\hline Model & $\begin{array}{c}\text { Independent } \\
\text { Variable }\end{array}$ & Dependent Variable & $\mathbf{R}^{2}$ & $\beta$ & $\mathbf{t}$ & $\begin{array}{c}\text { P Değeri } \\
(\beta)\end{array}$ \\
\hline 1 & $\begin{array}{l}\text { Work-Family } \\
\text { Conflict }\end{array}$ & Social shopping & .279 & -.113 & -1.111 & .269 \\
\hline 2 & $\begin{array}{c}\text { Work-Family } \\
\text { Conflict }\end{array}$ & Adventurous shopping & .116 & .060 & .765 & .446 \\
\hline 3 & $\begin{array}{l}\text { Work-Family } \\
\text { Conflict }\end{array}$ & Shopping for relaxation & .474 & -.469 & -4.716 & .000 \\
\hline 4 & $\begin{array}{c}\text { Work-Family } \\
\text { Conflict }\end{array}$ & $\begin{array}{c}\text { Shop to make others } \\
\text { happy }\end{array}$ & .295 & -.121 & -1.116 & .267 \\
\hline 5 & $\begin{array}{l}\text { Work-Family } \\
\text { Conflict }\end{array}$ & Shop for ideas & .382 & -.355 & -3.986 & .000 \\
\hline 6 & $\begin{array}{l}\text { Work-Family } \\
\text { Conflict }\end{array}$ & Shop for value & .310 & -.255 & -3.067 & .003 \\
\hline 7 & $\begin{array}{l}\text { Family-Work } \\
\text { Conflict }\end{array}$ & Social shopping & .279 & .460 & 3.195 & .002 \\
\hline 8 & $\begin{array}{l}\text { Family-Work } \\
\text { Conflict }\end{array}$ & Adventurous shopping & .116 & .056 & .503 & .616 \\
\hline 9 & $\begin{array}{c}\text { Family-Work } \\
\text { Conflict }\end{array}$ & Shopping for relaxation & .474 & .805 & 5.743 & .000 \\
\hline 10 & $\begin{array}{l}\text { Family-Work } \\
\text { Conflict }\end{array}$ & $\begin{array}{c}\text { Shop to make others } \\
\text { happy }\end{array}$ & .295 & .519 & 3.389 & .001 \\
\hline 11 & $\begin{array}{c}\text { Family-Work } \\
\text { Conflict }\end{array}$ & Shop for ideas & .382 & .523 & 4.163 & .000 \\
\hline 12 & $\begin{array}{l}\text { Family-Work } \\
\text { Conflict }\end{array}$ & Shop for value & .310 & .390 & 3.337 & .001 \\
\hline
\end{tabular}

As a result of the analysis of the data, the decisions regarding the hypotheses of the research are shown in the table below. 
İ. Erdoğan Tarakçı - B. Göktaş 11/3 (2019) 2216-2230

Table 6: Decisions on the Basic Hypotheses of the Study

\begin{tabular}{|c|l|}
\hline Hypothesis & Karar \\
\hline H1 & Rejected \\
\hline H2 & Rejected \\
\hline H3 & Rejected \\
\hline H4 & Rejected \\
\hline H5 & Rejected \\
\hline H6 & Accepted \\
\hline H7 & Rejected \\
\hline H8 & Accepted \\
\hline H9 & Accepted \\
\hline H10 & Accepted \\
\hline H11 & Accepted \\
\hline H12 & Rin \\
\hline
\end{tabular}

The hypotheses of the study test whether there is a positive relationship between work-family and familywork conflict on hedonic consumption, in other words, whether family-work and work-family conflict directs participants to hedonic consumption. Therefore, the hypothesis $\mathrm{H} 3, \mathrm{H} 5$ and $\mathrm{H} 6$, in which a negative relationship was found, were also rejected.

\section{CONCLUSIONS AND RECOMMENDATIONS}

Work and family make up a large part of the lives of individuals. Especially in recent years, the fact that many women have started working and more families have double income has changed their job and family roles. Therefore, it has become more important than ever for individuals to balance their work and family life.

The roles that people play in business and family life shape their lifestyles and also their needs and demands. Therefore, the conflict arising from the lack of stabilize between work and family tasks also affects the social lives of individuals and consequently the habits of consumption changes.

In this study, it is tried to determine whether work-family conflict or family-work conflict leads consumers to hedonic consumption. Here, there are two independent variables, work-family conflict levels and family-work conflict levels, and the effect of these two independent variables on hedonic buying behavior is tested. For this purpose, a survey was conducted to 412 blue and white collar workers who were actively working in factories operating in Bilecik and Bayburt Organized Industrial Zone between July-August 2019. 22 missing or incorrectly filled questionnaires were eliminated and 390 robust questionnaires were analyzed.

According to the study findings, work-family conflict has no effect on social shopping, adventurous shopping and shopping to make others happy dimensions, while it has a negative effect on shopping for relaxation, shopping to get ideas and shopping for value dimensions. On the other hand, family-work conflict has a positive effect on all dimensions of hedonic consumption except the adventurous shopping dimension. So, $\mathrm{H1}, \mathrm{H} 2, \mathrm{H} 3, \mathrm{H} 4, \mathrm{H} 5, \mathrm{H} 6, \mathrm{H} 8$ hypotheses are rejected and H7, H9, H10, H11 and $\mathrm{H} 12$ hypotheses are accepted. The strongest effect is on shopping for relaxation dimension. 


\section{İ. Erdoğan Tarakçı - B. Göktaş 11/3 (2019) 2216-2230}

Also this study supports the claim that WFC is higher than FWC, according to the means of the items. But WFC has no effect on hedonic consumption and FWC has positive effect on hedonic consumption except adventurous shopping. According to the findings, the biggest effect of the Family-Work Conflict is on "shopping for relaxation" $(0,805)$ so it can be said that consumers make hedonic consumption to cope with the stress created by family life on business life and to relax. This is followed by "shopping to get idea" and "shopping to make others happy". These are the ways consumers deal with stress created by FWC.

The fact that only $8.5 \%$ of the respondents stated that they never shop without thinking and unplanned, and that $70 \%$ stated that they would give up a product that they needed to buy a product that they would enjoy, revealed that hedonic consumption was quite high. Especially the fact that only $5.4 \%$ of the participants have an income of more than 5000TL and their income levels are not very high in general, however, the high level of hedonic consumption habits shows how effective the family business conflict stress is on the consumption habits.

On the other hand, $44.6 \%$ of the participants stated that they work over 40 hours. This shows that they are constantly working overtime. Despite this situation, the stress created by work on family life does not increase hedonic consumption. Almost half (46.2\%) of the participants do not have children, which may be a reason for this.

For the future studies, the choice of random sampling methods will be more effective in terms of generalizability of the study. Also this research is carried out in factories in limited sectors located in Bilecik and Bayburt Organized Industrial Zones and it would be beneficial to repeat the same or similar studies for different sectors.

\section{REFERENCES}

Aktepe, C. and Uygur, A. (2004). Finans Sektöründe Faaliyet Gösteren Kamu ve Özel Kesim İşletme Yöneticilerinin Önderlik Davranışlarını Ölçmeye Yönelik Bir Alan Araştırması. Ticaret ve Turizm Eğitim Fakültesi Dergisi, (1) , 60-83.

Albena, Z., Chiu, S.R.K. and Greenhaus, J.H. (2002). Negative Affectivity, Role Stress, and Work-Family Conflict. Journal of Vocational Behavior, 60(1), 1-16.

Allen, T.D. (2001). Family-Supportive Work Environments: The Role of Organizational Perceptions. Journal of Vocational Behavior, 58(3), 414-435.

Allen, T.D., Johnson, R.C., Saboe, K.N., Cho, E., Dumani, S. and Evans, S. (2011). Dispositional variables and work-family conflict: A meta-analysis. Journal of Vocational Behavior, 80, 17-26.

Arnould, M.J. and Reynolds, K.E. (2003). Hedonic Shoping Motivations. Journal Of Retailing, 79(2), 77-95.

Aycan, Z. (2005). Cross-Cultural Approaches to Work Family Conflict. Inaugural Conference on Work and Family Interface, Barcelona, Spain.

Aycan, Z. and Eskin, M. (2005). Relative Contributions of Childcare, Spousal Support, and Organizational Support in Reducing Work-Family Conflict for Men and Women: The Case of Turkey. Sex Roles, 53(78), 453-471.

Bruck, C.S., Allen, T.D. and Spector, P.E. (2002). The Relation between Work-Family Conflict and Job Satisfaction: A Finer-Grained Analysis. Journal of Vocational Behavior, 60, 336-353.

Byron, K. (2003). A meta-analytic review of work-family conflict and its antecedents. Journal of Vocational Behavior, 67, 169-198.

Carlson, D.S. (1999). Personality and Role Variables as Predictors of Three Forms of Work-Family Conflict. Journal of Vocational Behavior, 55(2), 236-253.

Carlson, D.S. and Perrewe, P.L. (1999). The Role of Social Support in the Stressor-Strain Relationship: An Examination of Work-Family Conflict. Journal of Management, 25(4), 513-540.

Carlson, D.S., Kacmar, K.M. and Williams, L.J. (2000). Construction and Initial Validation of a Multidimensional Measure of Work-Family Conflict. Journal of Vocational Behavior, 56(2), 249-276. 


\section{İ. Erdoğan Tarakçı - B. Göktaş 11/3 (2019) 2216-2230}

Cinamon, R.G. and Rich, Y. (2002). Gender Differences in the Importance of Work and Family Roles: Implications for Work-Family Conflict. Sex Roles, 47(11-12), 531-541.

Cinamona, R.G. and Rich, Y. (2005). Work-family conflict among female teachers. Teaching and Teacher Education, 21(4), 365-378.

DiRenzo, M.S., Greenhaus, J.H. and Weer, C.H. (2011). Job level, demands, and resources as antecedents of work-family conflict. Journal of Vocational Behavior, 78(2), 305-314.

Doğrul, Ü. (2012). Elektronik Alışveriş Davranışında Faydacı ve Hedonik Güdülerin Etkisi. Sosyal ve Beşeri Bilimler Dergisi, 4(1).

Erdoğan, İ. (1994). İşletmelerde Davranış. Beta Yayınları, İstanbul.

Erdoğan Tarakçı, İ. and Baş, M. (2019). Yaşam Doyumu ve Hedonik Tüketim İlişkisi Üzerine Ampirik Bir Çalışma, (Ed. Öztürk, S., Disiplinler Arası İktisat ve İşletme Araştırmaları), Iksad Publications: Ankara.

Erkenekli, M. (2001). Rol Kavramı ve Örgütsel Rol Modeli. Kara Harp Okulu Bilim Dergisi, 11(1), 43-57.

Frone, M.R., Russell, M. and Cooper, M.L. (1992). Prevalence of work-family conflict: Are work and family boundaries asymmetrically permeable?. Journal of Organizational Behavior, 13, 723-729.

Frone, M.R., Russell, M. and Cooper, M.L. (1997). Relation of work-family conflict to health outcomes: A fouryear longitudinal study of employed parents. Journal of Occupational and Organizational Psychology, 70(4), $325-335$.

Genç, N. (2004). Yönetim ve Organizasyon. Seçkin Basım, Ankara.

Greenhaus, J. H. and Beutell, N.J. (1985). Sources of Conflict between Work and Family Roles. Academy of Management Review, 10(1), 76-88.

Greenhaus, J.H., Ziegert, J.C. and Allen, T.D. (2012). When family-supportive supervision matters: Relations between multiple sources of support and work-family balance. Journal of Vocational Behavior, 80(2), 266275.

Gutek, B.A., Searle, S. and Klepa, L. (1991). Rational versus Gender Role Explanations for Work-Family Conflict. Journal of Applied Psychology, 76(4), 560-568.

Hasyurt, R. (2017). İş - Aile Çatışması ve İşten Ayrılma Niyeti İlişkisi: İstanbul'da Enerji Sektöründe Türk ve Çinli Yönetici Çalıştıran Bir İşletme Örneği. Yayımlanmamış Yüksek Lisans Tezi, Gazi Üniversitesi Sosyal Bilimler Enstitüsü, Ankara.

Hirschman, E.C. and Holbrook M.B. (1982). Hedonic Consumption: Emerging Concepts, Methods and Propositions. Journal of Marketing. 46 (2), 92-101.

Ishaya, N. and Ayman, R. (2008). Predicting Work-Family Conflict via Perceived Involvement and Overload. American Psychological Association (international project 3535), Boston, MA.

Jackson, S.E. and Schuler, R.S. (1985). A Meta-Analysis and Conceptual Critique of Research on Role Ambiguity and Role Conflict in Work Settings. Organizational Behavior and Human Decision Process, 36(1), 16-78.

Michel, J.S. and Hargis, M.B. (2008). Linking mechanisms of work-family conflict and segmentation. Journal of Vocational Behavior, 73(3), 509-522.

Karatepe, O.M. and Uludağ, O. (2008). Affectivity, conflicts in the work-family interface, and hotel employee outcomes. International Journal of Hospitality Management, 27(1), 30-41.

Kılıç, S. (2016). Cronbach'ın Alfa Güvenirlik Katsayısı. Journal of Mood Disorders, 6(1), 47-48.

Koçel, T. (2001). İşletme Yöneticiliği. Beta Yayın, İstanbul.

Lapierre, L.M., Spector, P.E., Allen, T.D., Poelmans, S., Cooper, C.L., O’Driscoll, M.P., Sanchez, J.I., Brough, P. and Kinnunen, U. (2008). Family-supportive organization perceptions, multiple dimensions of work- 
family conflict, and employee satisfaction: A test of model across five samples. Journal of Vocational Behavior, 73(1), 92-106.

Logue, A.A. and Ayman, R. (2009). Role of Social Support and Work-Family Conflict on Turnover Intentions. ICWF Conference, Barcelona, Spain.

Magnus, J.M. and Viswesvaran, C. (2009). The role of the coworker in reducing work-family conflict: A review and directions for future research. Pratiques Psychologiques, 15(2), 213-224.

Magnus, J.M. and Viswesvaran, C. (2003). Convergence between measures of work-to-family and family-towork conflict: A meta-analytic examination. Journal of Vocational Behavior, 67(2), 215-232.

Michel, J.S., Mitchelson, J.K., Kotrba, L.M., LeBreton, J.M. and Baltes, B.B. (2008). A comparative test of workfamily conflict models and critical examination of work-family linkages. Journal of Vocational Behavior, 74, 199-218.

Nielson, T.R., Carlson, D.S. and Lankau, M.J. (2001). The Supportive Mentor as a Means of Reducing WorkFamily Conflict. Journal of Vocational Behavior, 59(3), 364-381.

Odabaşı, Y. (2006). Tüketim Kültürü, Yetinen Toplumdan Tüketen Topluma. 2. Baskı, Sistem Yayıncılık, İstanbul.

Özdevecioğlu, M. and Çakmak Doruk, N. (2009). Organizasyonlarda İş-Aile ve Aile İş Çatışmalarının Çalışanların İş ve Yaşam Tatminleri Üzerindeki Etkisi. Erciyes Üniversitesi İktisadi ve İdari Bilimler Fakültesi Dergisi, 33, 69-99.

Rotondo, D.M., Carlson, D.S. and Kincaid, J.F. (2003). Coping with multiple dimensions of work-family conflict. Personnel Review, 32(3), 275-296.

Schermerhorn, A.R., Hunt, J.G. and Osborn, R.N. (1994). Managing Organizational Behavior. John Wiley\& Sons Inc., New York.

Shockley, K.M. and Allen, T.D. (2007). When flexibility helps: Another look at the availability of flexible work arrangements and work-family conflict. Journal of Vocational Behavior, 71, 479-493.

Tolan, B. (1994). Sosyal Psikoloji. Adım Yayıncılık, Ankara.

Torlak, Ö. (2000). Tüketim: Bireysel Eylemin Toplumsal Dönüşümü. İnkılap Yayınları, İstanbul.

Voydanoff, P. (1988). Work Role Characteristics, Family Structure Demands, and Work-Family Conflict. Journal of Marriage and Family, 50(3), 749-761.

Wayne, J.H., Musisca, N. and Fleeson, W. (2002). Considering the role of personality in the work-family experience: Relationships of the big five to work-family conflict and facilitation. Journal of Vocational Behavior, 64(1), 108-130.

Yaşar, M. (2014). İstatistiğe Yönelik Tutum Ölçeği: Geçerlilik ve Güvenirlik Çalışması. Pamukkale Üniversitesi Eğitim Fakültesi Dergisi, 36(2), 59-75.

Yıldırım, D. and Aycan, Z. (2008). Nurses' work demands and work-family conflict: A questionnaire survey. International Journal of Nursing Studies, 45(9), 1366-78.

Zhao, X.R., Qu, H. and Ghiselli, R. (2011). Examining the relationship of work-family conflict to job and life satisfaction: A case of hotel sales managers. International Journal of Hospitality Management, 30(1), 46-54.

\section{INTERNET SOURCES}

Turkish Language Association, http://www.tdk.gov.tr, Access: 30.07.2019. 